\title{
A Comparative Evaluation on the Oxidative Approaches for Extraction of Humic Acids from Low Rank Coal of Mukah, Sarawak
}

\author{
Sim Siong Fong, * Lau Seng, Norrafidah Bt Majri and Haslinda Bt Mat \\ ${ }^{a}$ Faculty of Resource Science \& Technology, University Malaysia Sarawak 94300 Kota \\ Samarahan, Sarawak, Malaysia
}

\begin{abstract}
Produtos derivados de ácidos húmicos têm bom mercado; entretanto, estes não são populares nessa região, devido ao alto custo imposto aos produtos importados. Por esta razão, é essencial identificar uma fonte nativa de ácidos húmicos como condicionador de solo. Carvões de baixa classe são encontrados em abundância em Mukah, com aplicação não energética largamente explorada. Estudos preliminares mostraram que o tratamento químico com ácido nítrico poderia aumentar potencialmente o rendimento essencial de ácidos húmicos de 20 a 85\%. Entretanto, ácido nítrico é um item caro, o que pode aumentar o custo, portando a possibilidade de empregar outros oxidantes precisa ser avaliada. Neste estudo, os ácidos húmicos foram extraídos de carvão de baixa classe de Mukah, com oxidação usando $\mathrm{HNO}_{3}, \mathrm{H}_{2} \mathrm{O}_{2}$ e $\mathrm{KMnO}_{4}$ e foram comparados em termos de rendimento, características químicas e espectroscópicas. Os resultados indicaram que a oxidação com $\mathrm{H}_{2} \mathrm{O}_{2}$ envolveu considerável perda de peso, sendo desfavorável para a produção de ácidos húmicos. A oxidação com permanganato de potássio não é recomendada, pois uma quantidade substancial de compostos inorgânicos foi introduzida aos produtos e o rendimento essencial obtido foi baixo. A oxidação com ácido nítrico continua sendo a escolha no processo de extração de ácidos húmicos, uma vez que a perda de massa envolvida foi aceitável; o rendimento de ácidos húmicos obtido foi alto com características de baixo teor de cinzas e alto teor de grupos funcionais ácidos.
\end{abstract}

Humic acid-based products are well marketed; nevertheless, these products remain unpopular in this region possibly due to the higher selling price resulted from the cost imposed on the imported products. For this reason, it is essential to identify the indigenous source of humic acids as the soil conditioner. Abundant of low rank coals are found in Mukah and the non-energy application of the source are largely unexplored. Preliminary study reported that chemical treatment with nitric acid could potentially increase the essential yield of humic acids from $20 \%$ to $85 \%$. Nitric acid is an expensive item, which could add on to the cost, hence possibility of employing other oxidative approaches need to be evaluated. In this study, the humic acids were extracted from the low rank coal of Mukah with $\mathrm{HNO}_{3}, \mathrm{H}_{2} \mathrm{O}_{2}$ and $\mathrm{KMnO}_{4}$ oxidation and were compared in terms of yield, chemical and spectroscopical characteristics. Results indicated that $\mathrm{H}_{2} \mathrm{O}_{2}$ oxidation involved considerable weight losses upon oxidation render it unfavorable for production of humic acids. Potassium permanganate oxidation however was not recommended, as a substantial amount of inorganic compounds was introduced to the products and the essential yield generated was low. Nitric acid oxidation remains the choice of the process for extraction of humic acids as the weight losses involved was acceptable; the yield of humic acids obtained was high with characteristics of low ash content and high acidic functional groups.

Keywords: coal, humic acids, nitric acid, potassium permanganate, hydrogen peroxide

\section{Introduction}

Coal is generally known as the source of energy that contains carbon, hydrogen, oxygen, nitrogen, sulfur and inorganic constituents. It is also regarded as the source of humic acids that is of vital importance in agriculture

*e-mail: sfsim@frst.unimas.my application. Humic acids are used as natural fertilizer and soil conditioner to remediate soil structure and to improve plant growth. Addition of humic substances extracted from an oxidized coal to soil was found to retard the onset of runoff process under rainfall. ${ }^{1}$ An increase in soil cation exchange capacity, $\mathrm{pH}$ and organic matter was also observed after incorporation of coal derived humic acids on two Nigerian nutrient poor tropical soils. ${ }^{2}$ In terms of plant growth, 
application of humic acids to various medium was reported to produce significant growth responses on the root, shoot and foliar. ${ }^{3}$ The most conclusive influence demonstrated include: $i$ ) improved rates of seed germination and seedling development, ii) enhanced root initiation and growth and iii) stimulated shoot growth. ${ }^{4}$ Owing the effectiveness investigated, manufacturers are promoting the use of humic acid-based products in agriculture. These products are gaining acceptance from the agriculture community as well as government institutions.

Humic acid-based products are apparently well established elsewhere. However, it is relatively unpopular in this region possibly due to the higher selling price compared to other soil conditioners. The cost imposes on the imported humic acid-based products render them unfavorable by the local growers. Therefore, attempts are essentially important to identify the potential of the indigenous coal as a source of humic acids for agriculture application. Abundant of low rank coals are found in Mukah and they are mainly mined for energy application. Preliminary study was performed to investigate the potential of the coal for industrial preparation of humic acids. The essential yield concluded was insufficient for economic possibilities. ${ }^{5}$ Nevertheless, oxidative pretreatment approach with nitric acid was incorporated to convert the coal to humic acids, and the results indicated a substantial improve in the yield from $20 \%$ to $85 \%$ suggesting the possibility of the low rank coal for commercial production of nitrohumic acids. Nitric acid is no doubt an effective material but it is an expensive item. Patti et al. ${ }^{6}$ evaluated the cost and benefit of nitric acid oxidation indicating doubtful economic potential of the process.

Therefore, the objective of this paper was to evaluate other possible oxidation processes for production of humic acids such as hydrogen peroxide $\left(\mathrm{H}_{2} \mathrm{O}_{2}\right)$ and potassium permanganate $\left(\mathrm{KMnO}_{4}\right)$ oxidations. The essential yield, chemical and spectroscopical characteristics of humic acids extracted with $\mathrm{H}_{2} \mathrm{O}_{2}$ and $\mathrm{KMnO}_{4}$ oxidation were compared with the humic acids extracted with nitric acid oxidation.

\section{Experimental}

\section{Preparation of coal sample}

Mukah coal sample was pulverized and sieved through $50 \mu \mathrm{m}$ sieve. The retained sample was kept for oxidation and extraction process.

\section{Coal oxidation}

The oxidizing procedure for $\mathrm{H}_{2} \mathrm{O}_{2}$ was based on Elbeyli and Pİşkin. ${ }^{7}$ The coal sample was treated with $5 \%$ and $10 \%$ of $\mathrm{H}_{2} \mathrm{O}_{2}$ ( $1 \mathrm{~g}$ of coal sample with $8 \mathrm{~g}$ of $\mathrm{H}_{2} \mathrm{O}_{2}$ solution) in water bath circulation for $2 \mathrm{~h}$ at constant temperature of $70{ }^{\circ} \mathrm{C}$. The mixture was filtered through $50 \mu \mathrm{m}$ sieve and washed with distilled water prior to oven drying at $105^{\circ} \mathrm{C}$ for $24 \mathrm{~h}$. Similarly, the coal sample was treated with $\mathrm{KMnO}_{4}$ in $1 \%$ of $\mathrm{KOH}$ and $\mathrm{HNO}_{3}$ with $1 \mathrm{~g}$ of coal in $5 \mathrm{~mL}$ of solution. The oxidation of coal with $\mathrm{HNO}_{3}, \mathrm{H}_{2} \mathrm{O}_{2}$ and $\mathrm{KMnO}_{4}$ were performed under acidic, moderately acidic and alkali condition, respectively.

\section{Weight losses}

Weight losses (on dry basis) of the coal samples were determined as follow:

Weight losses, $\%=\frac{(\mathrm{g} \text { coal })-(\mathrm{g} \text { residual coal })}{(\mathrm{g} \text { coal })} \times 100$

\section{Extraction of humic acids}

The humic acids were extracted according to the standard procedure described by $\mathrm{Swift}^{8}$ with modifications. One gram of coal was treated with $10 \mathrm{~mL}$ of 0.5 mol L-1 $\mathrm{KOH}$ at $70{ }^{\circ} \mathrm{C}$ for $2 \mathrm{~h}$. The supernatant was filtered through $50 \mu \mathrm{m}$ sieve and the coal residue was washed with distilled water until the supernatant was clear. The supernatant was acidified with concentrated $\mathrm{H}_{2} \mathrm{SO}_{4}$ to $\mathrm{pH}$ 1-2 and allowed to stand for $24 \mathrm{~h}$. The precipitated humic acids were separated by centrifugation. The gel-liked humic acids were oven-dried at $60{ }^{\circ} \mathrm{C}$ and stored in desiccators. Extreme temperature was not employed for the drying process as study indicated that excessive temperature deactivated humic acids and as a result higher application rates were required to obtain desirable yield responses. ${ }^{9}$ Humic acids extracted without undergoing the oxidation process is referred to as reference humic acids.

\section{Yield of humic acids}

The crude yield of humic acids was calculated as the weight of extracted humic acids per unit weight of coal. The actual yield of humic acids was obtained after subtracting the moisture and ash content.

\section{Chemical characterization}

The moisture content was determined by drying the samples at $105{ }^{\circ} \mathrm{C}$ overnight. The ash content was determined by combustion of the samples at $800{ }^{\circ} \mathrm{C}$ for 2 h. ${ }^{10}$ The total acidity was measured using the barium hydroxide method and the carboxyl groups were 
determined by using calcium acetate method. The phenolic content was calculated as the difference between the total acidity and the carboxyl groups. ${ }^{11}$

\section{Spectroscopic characterization}

\section{FTIR}

FTIR spectra of the samples were recorded on $\mathrm{KBr}$ pellets (2 mg humic acids and $100 \mathrm{mg} \mathrm{KBr}$ ) using FTIR spectrophotometer. All of the spectra were selfdeconvoluted to improve the apparent resolution. For the study of the integrated area in the region of 1780-1500 $\mathrm{cm}^{-1}$, the spectra were self deconvoluted at Gamma factor of 2 and smoothing factor of $50 \%$.

\section{UV-vis}

Approximately $5.0 \mathrm{mg}$ of humic acids samples were dissolved in $25 \mathrm{~mL}$ of $0.05 \mathrm{~mol} \mathrm{~L}^{-1} \mathrm{NaHCO}_{3}$ solutions with $\mathrm{pH}$ adjusted to $8-9$ with $0.1 \mathrm{~mol} \mathrm{~L}^{-1} \mathrm{NaOH}$ to assist solubility. Absorbance at $400 \mathrm{~nm}, 465 \mathrm{~nm}, 600 \mathrm{~nm}$ and $665 \mathrm{~nm}$ were recorded. The $\mathrm{E}_{4} / \mathrm{E}_{6}$ value was calculated based on the ratio of absorbance at $465 \mathrm{~nm}$ and $665 \mathrm{~nm}$. Absorbance at $465 \mathrm{~nm}$ expresses presence of humic acids formed in initial humification stage and absorbance at $665 \mathrm{~nm}$ indicates presence of humic acids formed in wellhumified organic matter. ${ }^{12}$ The value of $\Delta \log \mathrm{K}$ coefficient, $\Delta \log \mathrm{K}=\log \mathrm{A}_{400}-\log \mathrm{A}_{600}$, was calculated to categorize the degree of humification. ${ }^{13}$

\section{Statistical analysis}

Analysis of Variance (ANOVA) was employed to evaluate the significant differences in the acidic functional characteristics of humic acids prepared with different oxidation approaches.

\section{Results and Discussions}

\section{Yield of humic acids}

Table 1 summarizes the yield of humic acids (HA) prepared with various oxidation processes with $100 \mathrm{~g}$ of coal. The oxidation processes were observed to result in weight losses due to solubilization to various extents. Generally, reaction that leads to high losses is not favorable, as the yield will be reduced.

As evidenced, $\mathrm{HNO}_{3}$ oxidation produced relatively higher percentage of humic acids compared to $\mathrm{H}_{2} \mathrm{O}_{2}$ and $\mathrm{KMnO}_{4}$ oxidations. The crude yield of humic acids prepared with $\mathrm{H}_{2} \mathrm{O}_{2}$ oxidation $(86.33 \%$ ) although appeared to be promising; the considerable weight losses of coal upon oxidation $(50.33 \%)$ render it incomparable. The losses were also observed to correspond to the concentration possibly due to prominent occurrence of desulfurization and demineralization. These processes were commonly reported for oxidation with $\mathrm{H}_{2} \mathrm{O}_{2}$. Mukherjee et al. ${ }^{14}$ oxidized sub-bituminous coal with $15 \% \mathrm{H}_{2} \mathrm{O}_{2}$ attained a removal of more than $76 \%$ pyretic sulfur, $70 \%$ sulfate sulfur, $5 \%$ organic sulfur and $14 \%$ ash. The oxidation rate was revealed to accelerate with $\mathrm{H}_{2} \mathrm{O}_{2}$ concentration; ${ }^{15}$ therefore, more coal became soluble with increased concentration resulting in declination of the yield after oxidation. The prevalence of demineralization process in $\mathrm{H}_{2} \mathrm{O}_{2}$ oxidation explained the relatively lower ash content of the humic acids compared to others oxidized humic acids, particularly $\mathrm{KMnO}_{4}$ oxidation. For $\mathrm{KMnO}_{4}$ oxidation, previous study indicated that the degradation products were susceptible to undesirable inorganic substances such as manganese dioxide which are difficult to be removed. ${ }^{16}$ The interference is anticipated to be low in the present study as the oxidation was performed under alkali condition where insoluble $\mathrm{Mn}^{2+}$ predominated. However, without purification process with $\mathrm{HF} / \mathrm{HCl}$, the ash content could be significant. In terms of yield, the $\mathrm{KMnO}_{4}$ oxidation represented a rather reduced percentage and similar observation was reported by Almendros et al. ${ }^{17}$ and Reuter et al. ${ }^{18}$ even under the most favorable conditions. As a whole, the percentage yield of humic acids might depend on the reduction potential of the oxidizing agents under the aforementioned conditions. The reduction potential of $\mathrm{HNO}_{3}, \mathrm{H}_{2} \mathrm{O}_{2}$ and $\mathrm{KMnO}_{4}$ are $+0.803 \mathrm{~V}$, $+1.229 \mathrm{~V}$ and $+0.588 \mathrm{~V}$, respectively ${ }^{19}$ suggesting the order of oxidation as $\mathrm{H}_{2} \mathrm{O}_{2}>\mathrm{HNO}_{3}>\mathrm{KMnO}_{4}$.

Table 1. The yield of humic acids prepared with various oxidation processes with $100 \mathrm{~g}$ of coal

\begin{tabular}{lccccc}
\hline Oxidation & Weight losses/(\%) & Yield of crude $\mathrm{HA} /(\%)$ & Moisture/(\%) & Ash content/(\%) & Actual yield of HA/(\%) \\
\hline $5 \% \mathrm{HNO}_{3}$ & 12.60 & $88.37 \pm 2.64$ & $10.49 \pm 0.13$ & $2.41 \pm 0.36$ & 67.48 \\
$10 \% \mathrm{HNO}_{3}$ & 13.40 & $93.15 \pm 2.62$ & $14.92 \pm 0.13$ & $2.99 \pm 0.02$ & 66.58 \\
$5 \% \mathrm{H}_{2} \mathrm{O}_{2}$ & 32.23 & $63.57 \pm 7.32$ & $19.58 \pm 13.34$ & $2.40 \pm 0.46$ & 33.82 \\
$10 \% \mathrm{H}_{2} \mathrm{O}_{2}$ & 50.33 & $86.33 \pm 3.42$ & $16.06 \pm 5.33$ & $0.90 \pm 0.26$ & 35.68 \\
$5 \% \mathrm{KMnO}_{4}$ & 9.05 & $9.45 \pm 1.57$ & $12.73 \pm 1.57$ & $18.55 \pm 1.95$ & 6.11 \\
$10 \% \mathrm{KMnO}_{4}$ & 15.33 & $7.25 \pm 0.34$ & $21.10 \pm 8.09$ & $6.13 \pm 0.44$ & 5.83 \\
Reference $\mathrm{HA}$ & - & $10.07 \pm 1.01$ & $5.80 \pm 0.90$ & $4.45 \pm 0.14$ & 9.06 \\
\hline
\end{tabular}


Acidic functional characteristics of humic acids

Table 2 presents the acidic functional characteristics of humic acids prepared with various oxidation processes. Generally, the oxidative pretreatment processes resulted in an increase in the acidic functionality. This has been well discussed in the literatures. The degradation products of $\mathrm{KMnO}_{4}$ oxidation was found to be predominated by benzenepolycarboxylic acids, phenolic acids and fatty acids. ${ }^{17}$ Oxidation with nitric acids was reported to degrade the core structure of humic acids into a variety of aliphatic dicarboxylic acids, benzenecarboxylic acids, hydroxybenzoic acids and nitro compounds such as nitrophenols, nitrobenzoic acids and dinitrosalicyclic acids. ${ }^{20}$ In another study, Elbeylİ and Pİşkİn ${ }^{7}$ revealed a significant increase in $-\mathrm{OH},-\mathrm{COOH}, \mathrm{C}=\mathrm{O}$ and $\mathrm{C}-\mathrm{O}$ with $\mathrm{H}_{2} \mathrm{O}_{2}$ oxidation.

In addition to the increase in the acidic functional properties, the results indicated a variation in the $-\mathrm{COOH}$ and phenolic $\mathrm{OH}$ content over humic acids oxidized with different processes. No significant difference was revealed from the statistical analysis at $95 \%$ significant level for the phenolic $\mathrm{OH}$ content $(\mathrm{p}>0.05)$. For the $-\mathrm{COOH}$ content, a significant difference was identified suggesting the order of relative abundance of $-\mathrm{COOH}$ as $\mathrm{KMnO}_{4}$ $\mathrm{HA}<\mathrm{H}_{2} \mathrm{O}_{2}$-HA $<\mathrm{HNO}_{3}$-HA. The experimental results may underestimate the carboxylic content of $\mathrm{KMnO}_{4}-\mathrm{HA}$ as the carboxyl groups could be highly substituted with inorganic substances and they are hardly removed. A considerable improve was further noted for $\mathrm{HNO}_{3}-\mathrm{HA}$ prepared with higher concentration implying the relative harshness of $\mathrm{HNO}_{3}$ oxidation compared to $\mathrm{H}_{2} \mathrm{O}_{2}$ and $\mathrm{KMnO}_{4}$ oxidations. The relative abundance of the acidic functional groups indirectly reflected the intensity of the oxidation attack; however, the results are often subjected to uncertainty due to complex nature of humic substances. Polycarboxylic acids, for example, may exhibit a series of dissociation constants that decrease as successive protons dissociate. The substituted phenols on the other hand, are more strongly dissociated than the unsubstituted compound..$^{20}$

\section{Spectroscopic characterization of humic acids}

\section{$U V$-Vis properties of humic acids}

$\mathrm{E}_{4} / \mathrm{E}_{6}$ is an indicator of the degree of humification. A high ratio infers a low molecular weight and a greater level of aliphaticity. A low ratio however indicates a higher molecular weight with greater level of condensation. With reference to the UV-vis properties of humic acids in Table 2, apparently, oxidation processes produced humic acids with lower molecular weight than the original humic acids, indicative of structure fractionation. The fractionation was found to correspond to the intensity of oxidation as increased concentration consistently produced humic acids with lower molecular weight regardless of the oxidizing agent used. The oxidation processes involved cleavage of the condensation linkages that led to formation of humic acids with richer functionality and smaller fragments. The results implied that humic acids prepared with oxidation processes could possibly enhance the feature of humic acids as soil fertilizer and soil conditioner as Piccolo et $a l .^{21}$ concluded that humic acids with higher acidic functionality and smaller molecular size were the most effective fraction for plant nitrate uptake and growth regulations. The aliphatic and aromatic content of the extract were reported to be of no significant importance. According to the classification of $\operatorname{Kumada}^{13}$ based on the $\Delta \log \mathrm{K}$ coefficients; the humic acids were categorized as moderately humified with $\Delta \log \mathrm{K}$ ranging from $0.63-0.78$.

\section{FTIR properties of humic acids}

Figure 1 illustrates the FTIR spectra of humic acids prepared with different oxidation processes. The FTIR spectra of the oxidized humic acids were compared to the original humic acids with the software of Spectrum GX. Comparison of the spectra of $\mathrm{KMnO}_{4}-\mathrm{HA}, \mathrm{H}_{2} \mathrm{O}_{2}$ $\mathrm{HA}$ and $\mathrm{HNO}_{3}-\mathrm{HA}$ to the original humic acids attained correlation values of $0.9682,0.8821$ and 0.8739 , respectively. The results implied that there was a closer similarity between the structural features of the $\mathrm{KMnO}_{4}^{-}$ HA and the original HA. Basically, the spectra of humic acids prepared with various approaches consistently

Table 2. The acidic functional characteristics and UV-vis properties of humic acids prepared with various oxidation processes

\begin{tabular}{lcccc}
\hline Oxidation & -COOH/(mequiv. $\left.\mathrm{g}^{-1}\right)$ & Phenolic $\mathrm{OH} /\left(\right.$ mequiv. $\left.\mathrm{g}^{-1}\right)$ & Total acidity/(mequiv. $\left.\mathrm{g}^{-1}\right)$ & $\mathrm{E}_{4} / \mathrm{E}_{6}$ \\
\hline $5 \% \mathrm{HNO}_{3}$ & $3.97 \pm 1.49$ & $10.46 \pm 1.15$ & $14.43 \pm 0.44$ & $4.64 \pm 0.17$ \\
$10 \% \mathrm{HNO}_{3}$ & $7.70 \pm 1.75$ & $11.55 \pm 2.37$ & $19.25 \pm 1.58$ & $4.92 \pm 0.09$ \\
$5 \% \mathrm{H}_{2} \mathrm{O}_{2}$ & $4.02 \pm 0.16$ & $10.23 \pm 0.65$ & $14.24 \pm 0.79$ & $4.13 \pm 0.25$ \\
$10 \% \mathrm{H}_{2}$ & $4.09 \pm 0.23$ & $9.42 \pm 1.10$ & $13.51 \pm 0.99$ & $4.58 \pm 0.30$ \\
$5 \% \mathrm{KMnO}_{4}$ & $2.47 \pm 0.16$ & $6.94 \pm 1.06$ & $9.42 \pm 1.19$ & $4.42 \pm 0.11$ \\
$10 \% \mathrm{KMnO}_{4}$ & $2.49 \pm 0.15$ & $9.97 \pm 1.57$ & $12.45 \pm 1.50$ & $4.90 \pm 0.09$ \\
Reference HA $^{2}$ & $1.52 \pm 0.06$ & $7.09 \pm 1.72$ & $8.60 \pm 1.70$ & 0.63 \\
\hline
\end{tabular}


exhibited several important absorption bands in the region of $3,400 \mathrm{~cm}^{-1}, 2,920 \mathrm{~cm}^{-1}, 1,720 \mathrm{~cm}^{-1}$ and 1,615 $\mathrm{cm}^{-1}$. The broad band in the region of $3,400 \mathrm{~cm}^{-1}$ is attributed to the $\mathrm{OH}$ stretching of phenol and alcohol. The weak band at $2,920 \mathrm{~cm}^{-1}$ is assigned for the aliphatic $\mathrm{C}-\mathrm{H}$ stretching. The well-defined band at $1,720 \mathrm{~cm}^{-1}$ is due to the $\mathrm{C}=\mathrm{O}$ stretching of ketonic and carboxylic groups and the absorption band at $1,615 \mathrm{~cm}^{-1}$ is designated to the aromatic $\mathrm{C}=\mathrm{C}$ stretching. Other absorption bands on the FTIR spectra were at $1,100 \mathrm{~cm}^{-1}$ (C-O groups) and $600 \mathrm{~cm}^{-1}$ (sulfates) which is attributed to the treatment with sulfuric acids during the preparation process.

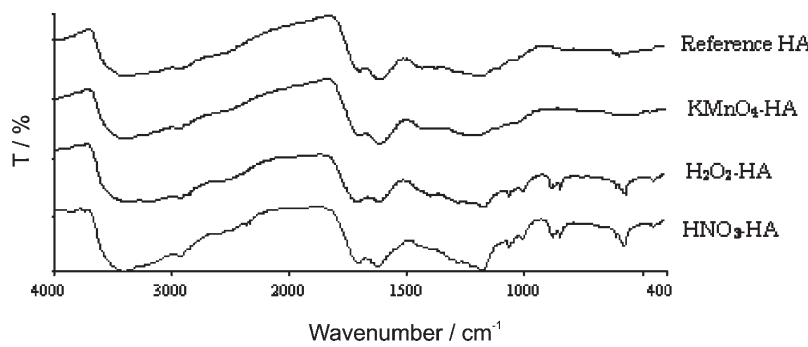

Figure 1. FTIR spectra of humic acids prepared with different oxidation processes.

It is observable that the band intensity at $1,720 \mathrm{~cm}^{-1}$ changes upon oxidation with different oxidizing agent. For $\mathrm{KMnO}_{4}$ oxidation, the band intensity at $1,720 \mathrm{~cm}^{-1}$ is relatively weaker possibly due to the prominent formation of metal-coordinated carboxylate. Two characteristics bands of $\mathrm{COO}^{-}$at $1,550 \mathrm{~cm}^{-1}$ and $1,400 \mathrm{~cm}^{-1}$ are evidenced on the FTIR spectra of $\mathrm{KMnO}_{4}$-HA supporting the prevailing formation of carboxylate ions. The absorption band at $1,720 \mathrm{~cm}^{-1}$ becomes rather pronounced for $\mathrm{HNO}_{3}-\mathrm{HA}$ and it appears to be stronger than the absorption band at $1,615 \mathrm{~cm}^{-1}$ for $\mathrm{H}_{2} \mathrm{O}_{2}$-HA indicating predominance of the oxygenated functional groups. Griffith et al..$^{22}$ reported that oxidation with $\mathrm{H}_{2} \mathrm{O}_{2}$ and $\mathrm{HNO}_{3}$ produced relatively higher portion of benzenecarboxylic acids. Others apparent different are demonstrated in the region below 1,600 $\mathrm{cm}^{-1}$. An ill-defined shoulder band at 1,540 $\mathrm{cm}^{-1}$ attributed to the presence of amide II (possibly nitrogroup due to oxidation of $\mathrm{HNO}_{3}$ ) is illustrated on the FTIR spectra of $\mathrm{HNO}_{3}$-HA. Furthermore, several additional bands with relatively strong intensity are found at $1,283 \mathrm{~cm}^{-1}, 1,069 \mathrm{~cm}^{-1}$ and $900-860 \mathrm{~cm}^{-1}$. The absorption band at $1,283 \mathrm{~cm}^{-1}$ is due to the oscillation of $\mathrm{C}-\mathrm{O}$ of phthalates and benzoate; the typical intense band at 1,069 $\mathrm{cm}^{-1}$ is ascribed for the alcohol groups and two neighboring bands with moderate intensity between $900-860 \mathrm{~cm}^{-1}$ are assigned for benzol ring with one to two unsubstitued hydrogen atom. These absorption bands are also identified on the FTIR spectra of $\mathrm{H}_{2} \mathrm{O}_{2}$-HA but are absent in the spectra of $\mathrm{KMnO}_{4}-\mathrm{HA}$. Referring to the absence of absorption bands between $900-860 \mathrm{~cm}^{-1}$, study reported that oxidation with alkaline $\mathrm{KMnO}_{4}$ yielded aromatic rings with high degree of substitution. In the products of such oxidation, tetra and pentacarboxylic acids predominated, whereas phthalic and benzoic acids formed from the rings with four or five unsubstituted hydrogen atoms were totally absent or in very small quantities. ${ }^{23}$

Fourier self deconvolution of the region between $1,780 \mathrm{~cm}^{-1}$ and $1,500 \mathrm{~cm}^{-1}$ was performed. The component bands were investigated in 9 sub-regions; 1,780$1,760 \mathrm{~cm}^{-1}$ (Ar-O-CO-R), 1,755-1,740 cm-1 (R-O-CO-

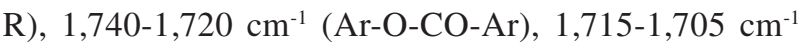
(Ar-CHO), 1,700-1,692 cm-1 (Ar-COOH), 1,690-1,655 $\mathrm{cm}^{-1}$ (Quinone $2 \mathrm{CO}$ in the same ring), 1,655-1,635 $\mathrm{cm}^{-1}$ (Ar-CO-Ar), 1,630-1,565 $\mathrm{cm}^{-1}$ (aromatic stretching) and $1,540-1,500 \mathrm{~cm}^{-1}\left(-\mathrm{COO}-\mathrm{M}^{+}\right)$. Assignments to these regions were referred to Calemma et al. ${ }^{24}$ The integrated areas of a definite functional group bands in different spectra were compared as relative measures of the amount of the relevant groups in different samples. ${ }^{25}$ Table 3 summarizes the peak area of the definite functional group bands in different spectra.

For all humic acids analyzed, intensity attributed to ester functionalities [Ar-O-CO-R (1,780-1,760 $\left.\mathrm{cm}^{-1}\right)$, RO-CO-R (1,755-1,740 $\left.\mathrm{cm}^{-1}\right)$ and Ar-O-CO-R (1,740$\left.\left.1,720 \mathrm{~cm}^{-1}\right)\right]$ appeared to be the most prominent structure. The observation agreed with the results of the previous study which indicated that aliphatic, phenolic and benzenecarboxylic acids structure of humic acids were usually identified in the forms of esters. ${ }^{16}$ The formation of esters has been explained in terms of condensation reactions between carboxyl and hydroxyl groups. ${ }^{26}$ In addition to the typical condensation reaction, Robertson and Waters ${ }^{27}$ proposed another formation routes of esters groups as illustrated in Figure 2. Among the $\mathrm{C}=\mathrm{O}$ groups of esters, intensities of $\mathrm{C}=\mathrm{O}$ in the $\mathrm{R}-\mathrm{O}-\mathrm{CO}-\mathrm{R}$ and Ar$\mathrm{O}-\mathrm{CO}-\mathrm{R}$ structures were relatively greater than those in Ar-O-CO-Ar indicating that oxidation occurred exclusively on the aliphatic part of the coal structure. This observation is in accordance to the results reported by Yürüm and Altuntaş. ${ }^{25}$

Generally, oxidation with $\mathrm{HNO}_{3}$ and $\mathrm{KMnO}_{4}$ generated humic acids with consistently greater peak area than the original humic acids for absorption bands attributed to ArO-CO-Ar, Ar-CHO, Ar-COOH, Quinone $2 \mathrm{CO}$, Ar-CO-Ar, aromatic stretching and $\mathrm{COO}^{-} \mathrm{M}^{+}$. Oxidation of alkyl structures yielded aldehydes and carboxylic acids (reaction 1); oxidation of methylenic groups and phenolic structures led to formation of ketones (reaction 2) and quinone 
Table 3. The peak area of the definite functional group bands in different spectra

\begin{tabular}{|c|c|c|c|c|}
\hline Region $/ \mathrm{cm}^{-1}$ & Reference HA & $\mathrm{KMnO}_{4}$-HA & $\mathrm{H}_{2} \mathrm{O}_{2}-\mathrm{HA}$ & $\mathrm{HNO}_{3}-\mathrm{HA}$ \\
\hline 1,780-1,760 (Ar-O-CO-R) & 634.42 & 634.96 & 351.47 & 898.46 \\
\hline 1,755-1,740 (R-O-CO-R) & 351.62 & 557.25 & 101.69 & 233.61 \\
\hline 1,740-1,720 (Ar-O-CO-Ar) & 249.82 & 381.08 & 142.09 & 402.37 \\
\hline 1,715-1,705 (Ar-CHO) & 58.31 & 341.44 & 120.05 & 213.27 \\
\hline 1,700-1,692 (Ar-COOH) & 63.74 & 110.32 & 57.79 & 120.57 \\
\hline 1,690-1,655 (Quinone 2 CO) & 395.41 & 666.90 & 343.18 & 664.25 \\
\hline 1,655-1,635 (Ar-CO-Ar) & 209.68 & 280.38 & 291.46 & 575.49 \\
\hline $1,630-1,565$ (aromatic stretching) & 457.71 & 958.80 & 799.80 & 1343.52 \\
\hline $1,540-1,500\left(\mathrm{COO}^{-} \mathrm{M}^{+}\right)$ & 749.12 & 1005.39 & 970.32 & 1324.92 \\
\hline
\end{tabular}

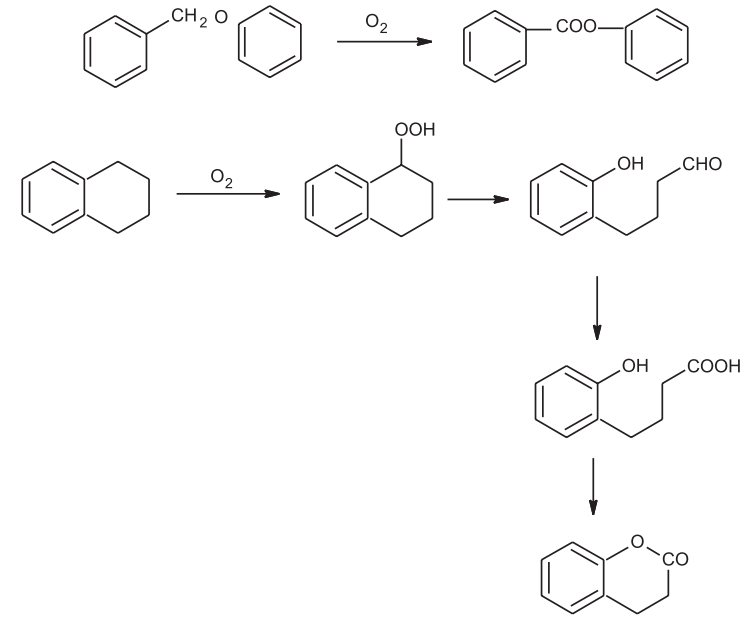

Figure 2. The proposed formation routes of ester groups.

(reaction 3), respectively. The presence of hydroxyl groups were also suggested to have activated the aromatic rings towards oxidation resulting in quinone..$^{28}$ Carboxylate ions were produced from structures containing carboxylic groups. Figure 3 presents the possible reactions during the oxidation process as described. ${ }^{25}$

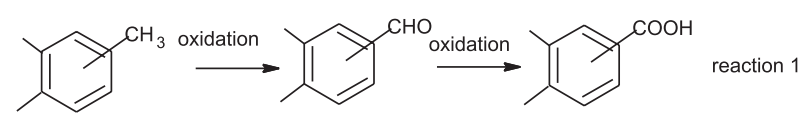<smiles>Cc1ccc(Cc2ccccc2)cc1Cc1ccc(C(=O)c2ccccc2)c(C)c1</smiles><smiles>Cc1cc2c(O)c3ccccc3c(O)c2cc1C</smiles>

Figure 3. Possible reaction during oxidation process.

The peak area of Ar-CHO and $\mathrm{Ar}-\mathrm{COOH}$ unexpectedly attained a relatively lower intensity than ester groups implying that methylene structures were more susceptible to oxidation than the alkyl structures. Theoretical considerations $^{29}$ and experimental evidence ${ }^{30}$ supported the present data indicating that benzylic methylene and methylene next to -OR groups were the sites most susceptible to oxidation. Prevailing substitution of $-\mathrm{COOH}$ to form $-\mathrm{COO}^{-} \mathrm{M}^{+}$as noted in the prominent peak area of the carboxylate ion could have also explained the lower intensity of the carboxylic groups. Generally, typical reactions that are expected to occur during oxidation managed the explanation on the evolution of the functional group bands for $\mathrm{KMnO}_{4}$ and $\mathrm{HNO}_{3}$ oxidation. However, oxidation with $\mathrm{H}_{2} \mathrm{O}_{2}$ exhibited abnormal trend with almost all of the functional groups bands studied having relatively lower intensity. Study indicated that oxidation with hydrogen peroxide produced humic acids with relatively greater aliphatic nature. Oxalic acid $[\mathrm{HOOCCOOH}]$ and malonic acid [HOOC- $\mathrm{CH}_{2}-\mathrm{COOH}$ ] were found to present in considerable quantities with small amount of glycolic acid $\left[\mathrm{HOCH}_{2} \mathrm{COOH}\right]$, succinic acid [HOOC- $\mathrm{CH}_{2} \mathrm{CH}_{2}-$ $\mathrm{COOH}]$ and mellitic acid $\left[\mathrm{C}_{6}(\mathrm{COOH})_{6}\right]{ }^{31}$ This possibly affords an explanation on the insignificant peak area of the aromatic based structures for $\mathrm{H}_{2} \mathrm{O}_{2}-\mathrm{HA}$.

\section{Conclusions}

Comparatively, $\mathrm{HNO}_{3}$ oxidation remains a better approach for production of humic acids as soil conditioners as the process involved acceptable losses of coal upon oxidation and yielded a substantial amount of products with low ash content and high acidic functional groups. For $\mathrm{KMnO}_{4}$ oxidation, the yield was relatively low and in addition the products contained a considerable amount of inorganic substances. $\mathrm{H}_{2} \mathrm{O}_{2}$ oxidation however, involved an apparent loss upon oxidation therefore is unfavorable. The yield of humic acids could be attributed to the oxidation potential of the oxidizing agents. Nevertheless, these three approaches invariably produced humic acids with higher acidic functional groups with the results suggest that humic acids generated with $\mathrm{H}_{2} \mathrm{O}_{2}$ oxidation were more aliphatic in nature. 


\section{Acknowledgment}

The authors wish to thank the University Malaysia Sarawak for financial support.

\section{References}

1. Piccolo, A.; Celano, G.; Environ.Toxicol. Chem. 1994, 13, 1737.

2. Piccolo, A.; Pietramellara, G.; Mbagwu, J. S. C.; Soil Technol. 1997, 10, 235.

3. Lulakis, M. D.; Petsas, S. I.; Bioresour. Technol. 1995, 54, 179.

4. Chen, Y.; Aviad, T. In Humic Substances in Soil and Crop Sciences: Effects of Humic Substances on Plant Growth; MacCarthy, P.; Clapp, C. E.; Malcolm, R. L.; Bloom, P. R., eds.; American Society of Agronomy and Soil Science Society of America: Madison, Wiscosin, 1990.

5. Fong, S. F.; Seng, L.; Chong, W. N.; Asing, J.; Md Nor, M. F.; Mohd Pauzan, A. S; J. Braz. Chem. Soc. 2006, 17, 582.

6. Patti, A. F.; Verheyen, T. V.; Douglas, L.; Wang, X.; Sci.Total Environ. 1992, 113, 49.

7. Elbeylİ, 0. Y.; Pİşkİn, S.; J. Eng. Natural Sci. 2004, 3, 43.

8. Swift, R. S. In Methods of Soil Analysis Part 3: Chemical Methods (SSSA Book Series No.5); Spark, D. L. ed.; SSSA and ASSA: Madison, WI, 1996.

9. Freeman, P. G.; Fowles, W. W; US Dept. of Interior Bureau of Mines Report of Investigations, 1968, 7203.

10. Allen, S. E; Chemical Analysis of Ecological Materials, Blackwell Scientific: London, 1989.

11. Schnitzer, M. In Proc. Symposium on Soil Organic Matter Studies, International Atomic Energy Agency: Vienne, 1977.

12. Debska, B.; Maciejewska, A.; Kwiatkowska, J; Rostlinna Vyroba 2002, 48, 33.

13. Kumada, K; Food Fertility Technology Century. 1975, 22, 10.

14. Mukherjee, S.; Mahiuddin, S.; Borthakur, P. C.; Energy Fuels 2001, 15, 1418.

15. Palmer, S. R.; Hippo, E. J. L.; Dorai, X. A.; Fuel 1994, 73, 161.
16. Hayes, M. H. B.; MacCarthy, P.; Malcolm, R. L.; Swift, R. S. In Humic substances II. In search of structure; John Wiley \& Sons, Ltd.: Chichester, 1989.

17. Almendros, G.; González-Vila, F. J.; Martín, F.; Soil Biol.Biochem.1989, 21, 481.

18. Reuter, J. H.; Ghosal, M.; Chian, E. S. K.; Giabbai, M. In Aquatic and Terrestrial Humic Materials: Oxidative Degradation Studies on Aquatic Humic Substances; Christman, R. F.; Gjessing, E. T., eds.; Ann Arbor Science: Ann Arbor, 1983.

19. Porile, N. T.; Modern University Chemistry, McGraw-Hill, Inc: New York, 1993

20. Stevenson, F. J.; Humus Chemistry Genesis, Composition, Reactions, John Wiley \& Sons: New York, 1982.

21. Piccolo, A.; Nardi, S.; Concheri, G.; Soil Biol. Biochem. 1992, 24, 373.

22. Griffith, S. M.; Holder, M. B.; Munro, S.; Tropical Agriculture (Trinidad) 1984, 61, 213.

23. Orlov, D. S.; Humus Acids of Soils, Oxonian Press Pvt. Ltd: New Delhi, 1985.

24. Calemma,V.; Iwanski, P.; Rausa, R.; Girardi, E.; Preprints of papers - American Chemical Society, Division of Fuel Chemistry 1992, 37, 730.

25. Yürüm, Y.; Altuntaş, N.; Fuel 1998, 77, 1809.

26. Painter, P. C.; Snyder, R. W.; Pearson, D. E.; Kwong, J.; Fuel 1980, 59, 282.

27. Robertson, A.; Waters, W. A.; J. Chem. Soc. 1948, 1574.

28. Staude, E.; Patat, F. In Chemistry of the Ether Linkage; Patai, S., ed.; Wiley Interscience: New York, 1967.

29. Russel, A. G. In Free Radicals Vol. 1; Kochi, K., ed.; Wiley: London, 1973.

30. Hungtinton, J. G.; Mayo, F. R.; Kirshen, N. A.; Fuel 1979, 58, 31.

31. Brooks, V. T.; Lawson, G. J.; Ward, S.G.; Fuel 1956, 35, 385.

Received: May 15, 2006

Web Release Date: October 3, 2006 